\title{
ANALYSIS IMPORT POLICY OF SOYBEAN ON ECONOMICS PERFORMANCE OF INDONESIAN SOYBEAN
}

\author{
Muthiah Abda Azizah $^{1^{*}}$, Syafrial ${ }^{2}$, Suhartini ${ }^{2}$ \\ ${ }^{1}$ Postgraduate, Faculty of Agriculture, University of Brawijaya, Veteran Street, Malang 65145, Indonesia \\ ${ }^{2}$ Department of Socioeconomics, Faculty of Agriculture, University of Brawijay, Veteran Street, Malang \\ 65145, Indonesia
}

Received: 13th October 2015; Revised: 3rd November 2015; Accepted: 3rd November 2015

\begin{abstract}
Trade liberalization is closely related with the opening of market access for Indonesian products to the world and viceversa. Since the soybean trade was independent from BULOG in 1998, soybean imports increased very rapidly (Sudaryanto and Swastika, 2007). This research aims to find out economy performance from soybean, analyses factors that influence the economic performance of Indonesian soybean and findings the alternative of policies that can reduce soybean imports in Indonesia. Methods of data analysis are descriptive analysis, 2SLS simultaneous equations, and simulation of policy alternatives. Results of the analysis of the factors that affect the economic performance of Indonesian soybean, consists of 1) The area of soybean harvest is influenced significantly by the price of domestic soybean and domestic prices of corn, 2) Productivity soybean influenced significantly by the domestic prices of soybean and fertilizer prices, 3) soybean demand influenced significantly by population, domestic prices of soybean, 4) domestic prices of soybean significantly affected by world prices of soybean, exchange rates, and soybean supply, 5) Imports of soybean influenced significantly by the domestic demand of soybean and soybean production. Therefore, policy scenarios should be made to reduce soybean imports, including by carrying out the expansion of soybean harvest policy, the policy to increase the productivity of soybean, the policy to subsidize the price of fertilizer.
\end{abstract}

Keywords: Trade liberalization; imports; soybeans; economic performance

\section{Introduction}

The process of trade liberalization characterized by established the General Agreement on Tariffs and Trade (GATT) in 1947 , which is now its role has been replaced by the World Trade Organization (WTO). The trading system of the WTO regulated through an agreement which contains the basic rules of international trade as a result of negotiations that have been signed by the member of States. Trade liberalization which has foster Indonesia to get profit for increasing economic growth through trade balance surplus. But keep in mind that the process of trade liberalization itself is closely related to the opening of market access of export products of Indonesia to the world. So Indonesia's involvement in various trade cooperation gives a challenge to domestic products (Halwani, 2005).

Agriculture is one of the sectors that very

\footnotetext{
*) Correspondence author

E-mail: muthiah.abdaazizah@gmail.com

Phone: +62-856-92524314
}

dominant in Indonesia (Badan Pusat Statistik, 2001). The agricultural sector includes the following subsector as food crops, horticulture, plantage, fishery, husbandry, and forestry subsector. One of the Indonesian food crops has a major actor for the Indonesian economy is soybean. Soybean is the main source of raw materials for the industry tahu, tempe, tauco, ketchup, and livestock feed.

Soybean has been known as a source of nabati protein but this commodity has never been a main food crop as well as rice (Supadi, 2009). Indonesia had achieved self-sufficiency in 1992 soybean as its farm area reached 1.6 million hectares. At that time farmers are interested in planting soybean because the prices of this commoditiy was 1.5 times of rice.

The development of a production, broad area of harvest, and yield of soybean in Indonesia in the past 20 years tend to be volatile every years. Farm area of soybeans began to decrease in 1995 , originally $1,477,430 \mathrm{Ha}$ into $615,019 \mathrm{Ha}$ in 2014. That case caused by the one of factors is the growing number of imported soybeans coming into Indonesia. So, many farmers are 
doing over the function because it admitted to not eager again to farm soybeans because soybeans import prices tend to be cheaper than the price of soybeans domestic.

Since the free control of soybean trade from BULOG starting in 1998 and since Indonesia is involved with the Treaty of ACFTA in 2010 import of soybeans has increased very rapidly (Sudaryanto and Swastika, 2007). The average import of soybean in Indonesia within a twenty year is $1,428,790$ tonnes per year. The amount of soybeans needs in Indonesia increases every year (Purwono and Purnamawati, 2007), yet the production of domestic soybean tends to decrease from year to year, it is that causes the higher imports to cover the needs of the national soybean production was only able to produce an average of 969,289 tons annually, while the average consumption amounted to $2,178,110$ tonnes.

Based on the explanation that has been exposed, so the research on the impacts of the import policy soybeans to economy activity of soybeans in Indonesia is important. As soybean is one of the food commodity that the demand of soybean tend to increase every years, but the conditions in the country are still poor of concern because the number of its production declined steadily from year to year. The purpose of this research is to know the development of the economic performance of soybeans, analyzing the impact of soybeans import policy on soybeans economy Indonesia performance, as well as seek alternative policies that can reduce the import of soybeans in Indonesia, thus the reliance of imported soybeans in Indonesia can be overcome.

\section{Research Methods}

Descriptive analysis is used to describe data related to economic performance of soybeans Indonesia starting 1989-2014. Quantitative analysis is used to analyze the impact of soybean import policy against economic performance soybeans Indonesia. some stages of analysis being performed include; stasioneritas-test that is performed prior to the estimation, the data used in this research was first seen from stasioneritas using the test root Union by using the ADF test (Argumented Dickey Fuller Test). Each variable is stationary if the value of the probability for the whole variable less than 0.05 and the value of the ADF (Argumented Dickey Fuller Test) test statistic is less than the value of the test critical value. Furthermore, the identification of model specifications model, method of prediction models, model testing, testing, validation parameters alleged model and simulation for policy can reduce the import of soybean in Indonesia.

\subsection{Economic Model Specifications of Soybeans}

1. Supply Model of Soybeans Indonesia

Supply Model soybeans Indonesia consists of several equations.

a. The Acreage of soybeans Indonesia:

$A t=a_{0}+a_{1} P K d t+a_{2} P J d t+a_{3} A_{t-1}+U_{1}$

b. The productivity of Soybeans Indonesia:

$\mathrm{YPKt}=\mathrm{b}_{0}+\mathrm{b}_{1} \mathrm{PKdt}+\mathrm{b}_{2} \mathrm{Pxt}+\mathrm{b}_{3} \mathrm{YPK}_{\mathrm{t}-1}+\mathrm{U}_{2}$

c. Production of soybeans Indonesia:

$\mathrm{QKIt}=$ At $*$ YPKt.

d. Supply of soybeans Indonesia:

QSKlt $=$ QKlt + MKlt

2. Demand of soybeans Indonesia

QDKIt $=\mathrm{d}_{0}+\mathrm{d}_{1} \mathrm{PKdt}+\mathrm{d}_{2} \mathrm{Ntt}+\mathrm{d}_{3} \mathrm{Ytt}+\mathrm{d}_{4} \mathrm{PJt}+$ $\mathrm{U}_{4}$

3. Model of Price soybeans Indonesia

PKdt $=\mathrm{e}_{0}+\mathrm{e}_{1}$ PKwt $+\mathrm{e}_{2}$ QDKIt $+\mathrm{e}_{3}$ QSKIt $+\mathrm{e}_{4}$ Er $+\mathrm{e}_{5} \mathrm{TMK}+\mathrm{e}_{6} \mathrm{PKw}_{\mathrm{t}-1}+\mathrm{U}_{7}$.

4. Import of soybenas Indonesia

MKIt $=\mathrm{c}_{0}+\mathrm{c}_{1} \mathrm{QKIt}+\mathrm{c}_{2} \mathrm{QDdt}+\mathrm{c}_{3} \mathrm{TMKt}+\mathrm{c}_{4} \mathrm{PKwt}$

$+\mathrm{c}_{5} \mathrm{Er}+\mathrm{U}_{3}$

Where:

QSKlt : Supply of Indonesia Soybeans

QKlt : Produkciton of Indonesia Soybeans

MKlt : Import of Soybeans in Indonesia

At : The Acreage of the soybeans in

Indonesia year of $\mathrm{t}$

YPKt : The Productivity of Soybeans in Indonesia

PKwt : Price of Soybeans in the world

PKdt : Price of Soybeans domestic

$A_{t-1} \quad$ : The Acreage of the soybeans in

Indonesia at the previous year

Pxt : Fertilizer Prices

$\mathrm{YPK}_{\mathrm{t}-1}$ : The productivity of soybeans in

Indonesia at the previous year

TMKt : Tariff Import Soybeans Indonesia

Er : Real Exchange Rate

QDKIt : demand of soybeans in Indonesia

$\mathrm{Ntt}$ : The total population of year $\mathrm{t}$ 
Ytt : The Income of the Inhabitants of Indonesia

PJt : Domestic Corn Prices

QDKI $_{t-1:}$ demand of soybeans in the world

$\mathrm{PKW}_{\mathrm{t}-1}$ : World Soybean prices previous year

\subsection{Model Identification}

The identification of the structural model is performed based on test order condition. Identification of results showed all equations over identified, then the methods of prediction model used in this study is the 2SLS (two stage least squares) by using the computer application program e-8 Views.

\subsection{Procedure Simulation}

The regression model in the simulation was performed through procedures of Non Linear Simulation (SIMLIN) on computer application program that is Statistical Analysis System (SAS). Simulation analysis of the conducted policies are:

1. The expansion of soybean crop acreage $15 \%$. It is based on the development of empirical data during the period of 1989 to 2014 and in accordance with the strategic plan of the Ministry of agriculture to achieve self-sufficiency of soybeans.

2. Increased productivity $10 \%$. It is based on the development of empirical data during the period of 1989 to 2014 and in accordance with the strategic plan of the Ministry of agriculture to achieve selfsufficiency of soybeans.

3. The granting of subsidies on fertilizer prices $10 \%$. It is based on the development of empirical data during the period of 1989 to 2014 and in accordance with one of the realization of how increased productivity within the strategic plan of the Ministry of agriculture.

\section{Results and Discussion}

\subsection{An Overview of The Condition of The Soybean Indonesia}

Development of soybean production in the past 26 years, namely 1989 to 2014 tend to decline each year. This is due to the extensive acreage harvested soybeans also experience a decrease each year due to price fluctuations of the soybean Indonesia as well as the competition with other commodities such as corn that uses the same land.
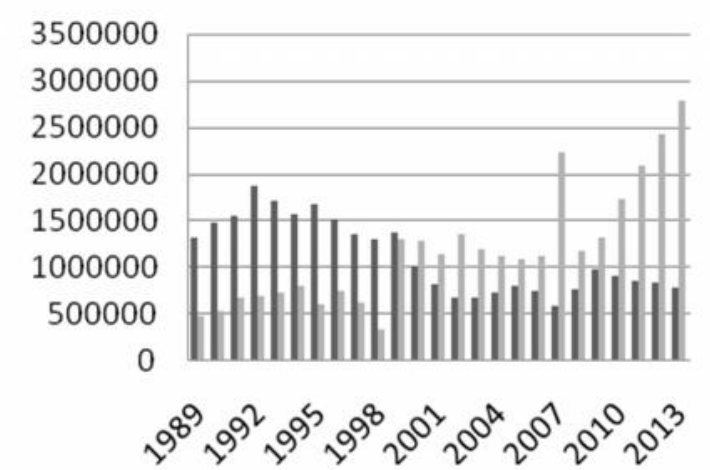

: Domestic Soybean Production $\square$ : Soybean Import

Figure 1. Soybean productions domestic and imported soybeans Indonesia from 1989-2014 (Tonnes) (Badan Pusat Statistik, 2015).

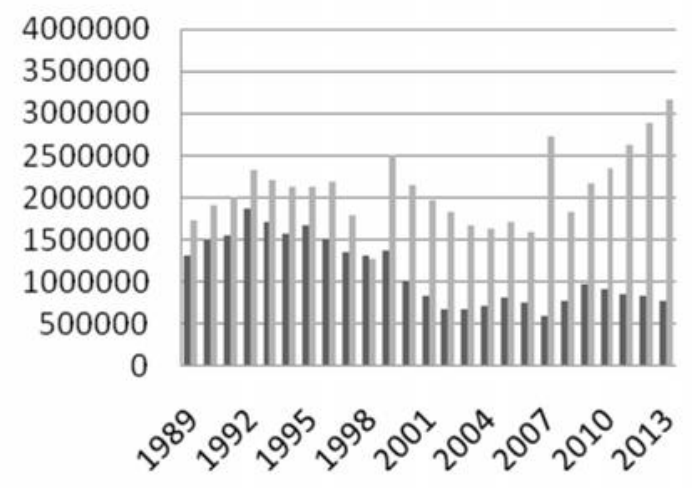

: Domestic Soybean Production $\square$ : Soybean Demand

Figure 2. The production of domestic soybean and demand of soybean Indonesia from 1989-2014 (Tons) (Badan Pusat Statistik, 2015).

The demands and imports of soybeans each year continues to increase. The largest increases occurred in 1999 and 2007, where in 1999 an increment of the electrical reform in 1998 which resulted in political and economic instability in Indonesia, while in 2007 the increase caused by the amount of soybeans production are very low (Indradewa, 2013). The price of domestic soybean and soybean prices world also increase every year. The largest increase occurred in 1997-1999 and 2004-2008, which in that year the global economic crisis and the situation of the economy in the country is not conducive (Amang and Sawit, 1996). 


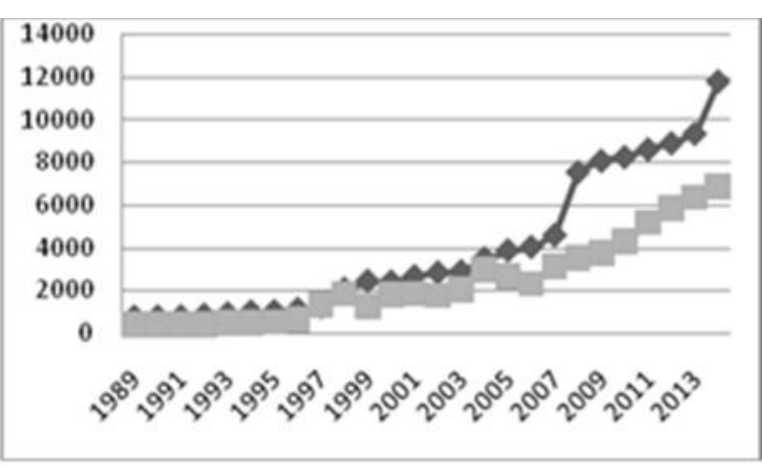

: Domestic Soybean Price $\square$ : World Soybean Price

Figure 3. Soybean domestic prices and soybeans world prices period 1989-2014 $(\mathrm{Rp} / \mathrm{Kg})$ (Badan Pusat Statistik, 2015).

\subsection{Factors That Affect Economic Performance of Soybean In Indonesia}

Based on Table 1. Population variable (Ntt), domestic corn price (PJDt), the price of soybeans world $(\mathrm{PKWt})$, the price of fertilizer (PXt), the amount of soybean production (QKIt), soybean (QSKIt) offer, the price of imported soybeans (TMK), and incomes (Ytt) have showed on the level of the stationary level. This is proven with absolute value greater than the ADF on absolute values in each Critical level Mackinnon real $(1 \%, 5 \%$, and $10 \%)$.

Other variables that have not been stationary at level level since the ADF value is still smaller than the absolute value for each Critical Mackinnon real levels $(1 \%, 5 \%$, and $10 \%)$. So the zero hypothesis should be accepted and thus carried out the first test of the difference to be able to menstasionerkan other variables.

Table 1. Stasioneritas test results (Badan Pusat Statistik, 2015 (Data Processed)).

\begin{tabular}{lccccc}
\hline Variable & \multirow{A}{*}{$\begin{array}{c}\text { ADF } \\
\text { Value }\end{array}$} & \multicolumn{3}{c}{$\begin{array}{c}\text { Mackinnon Critical } \\
\text { Value }\end{array}$} & \multicolumn{2}{c}{$\begin{array}{c}\text { Descripti } \\
\text { on }\end{array}$} \\
\cline { 2 - 5 } & & $\mathbf{1 \%}$ & $\mathbf{5 \%}$ & $\mathbf{1 0 \%}$ & \\
\hline Ntt & -4.394 & -3.612 & -3.374 & -3.243 & Stasioner \\
PJDt & -6.643 & -4.394 & -3.612 & -3.243 & Stasioner \\
PKWt & -5.527 & -4.416 & -3.622 & -3.248 & Stasioner \\
PXt & -6.227 & -4.394 & -3.612 & -3.243 & Stasioner \\
QKIt & -5.978 & -4.394 & -3.612 & -3.243 & Stasioner \\
QSKIt & -5.448 & -4.394 & -3.612 & -3.243 & Stasioner \\
TMK & -5.576 & -4.394 & -3.612 & -3.243 & Stasioner \\
Ytt & -4.394 & -3.815 & -3.612 & -3.243 & Stasioner \\
\hline
\end{tabular}

Table 2. show that the soybeans harvest area variable (At), soybeans harvested area a year earlier (At-1), the exchange rate (ER), the amount of imports of soybean in Indonesia (MKIt), imports of soybeans a year earlier (MKIt-1), the price of domestic soybean (PKDt), domestic soybean prices a year earlier (PKDt-1), the amount of soy demand (QDKIt), the number of soybeans demand a year earlier (QDKIt-1), soybeans (YPKt) productivity, and productivity of the previous year (YPKt-1) is already stationary at the level of the first difference.

Table 2. Stationary test results at the level of the first difference (Badan Pusat Statistik, 2015 (Data Processed)).

\begin{tabular}{lccccc}
\hline \multirow{2}{*}{ Variabel } & \multirow{2}{*}{$\begin{array}{c}\text { ADF } \\
\text { Value }\end{array}$} & \multicolumn{4}{c}{$\begin{array}{c}\text { Mackinnon Critical } \\
\text { Value }\end{array}$} \\
\cline { 3 - 5 } & & $\mathbf{1 \%}$ & $\mathbf{5 \%}$ & $\mathbf{1 0 \%}$ & \\
\hline At & -4.394 & -3.675 & -3.612 & -3.243 & Stasioner \\
At-1 & -4.440 & -3.632 & -3.265 & -3.254 & Stasioner \\
ER & -6.815 & -4.394 & -3.612 & -3.243 & Stasioner \\
MKIt & -4.597 & -4.394 & -3.612 & -3.243 & Stasioner \\
MKIt-1 & -6.702 & -4.416 & -3.622 & -3.248 & Stasioner \\
PKDt & -4.442 & -4.394 & -3.612 & -3.243 & Stasioner \\
PKDt-1 & -5.574 & -4.416 & -3.622 & -3.248 & Stasioner \\
QDKIt & -6.614 & -4.394 & -3.612 & -3.243 & Stasioner \\
QDKIt-1 & -7.339 & -4.416 & -3.622 & -3.248 & Stasioner \\
YPKt & -7.166 & -4.394 & -3.612 & -3.243 & Stasioner \\
YPKt-1 & -4.440 & -3.815 & -3.632 & -3.254 & Stasioner \\
\hline
\end{tabular}

1. The Factors That Affect The Soybeans Harvested Area in Indonesia

Based on the results of the calculations which are obtained that the value of the Fstatistic (103.231) is greater than the F-table (7.938) which means that the variables are exogenous effect together/simultaneous against acreage harvested soybeans. The value of the coefficient of determination is obtained of 0.938 or $93.8 \%$ which means that the acreage of the soybean crop variation can be explained by exogenous variables that include the price of domestic soybean (PKDt), domestic corn price (PJDt), and the harvest area in the previous year (At-1), while $6.2 \%$ of the soybean harvested area, spacious variation explained by other factors outside the model. Factors that affect the soybeans harvested area Indonesia is as follows:

\section{a. Domestic Soybean Price \\ Domestic soybean price has positive effect} against the acreage of the soybean crop in Indonesia. It is apparent from the results of the test $t$ with $p$-value (0.096) a significant level of errors of $10 \%$. The value of domestic soybean price parameter coefficient (108.9005) indicates that in the event of domestic soybean price increases by 1 unit, then it would cause a rise or 
increase harvest of soybean 108.9005 spacious units with a confidence level of $90 \%$. So instead.

\section{b. Domestic Corn Price}

Corn Price domestichas negative effect to the acreage of the soybean crop in indonesia. It is apparent from the $\mathrm{t}$ value with $\mathrm{p}$-value $(0.050)$ that is significant at a 5\% error level. The value of the coefficient of domestic corn price parameters $(-340,0321)$ indicates that in the event of domestic corn price increases by 1 unit, then it will cause a decline in the broad area of soybean harvest of 340,0321 units with a confidence level of $95 \%$. So did the opposite.

c. The Soybeans Harvested Area in Previous Year

The soybeans harvested area in the previous year has positive effect against the harvested area of the soybean crop in Indonesia. It can be observed from the results of the test $t$ with p-value (0.000) to a significant extent on the error of $1 \%$. The value of the coefficient of the broad parameters of the soybean crop acreage years earlier (0.82161) shows that in case of extensive acreage increase soybean harvest in previous years by 1 unit, then it would cause a rise or increase harvest of soybeans acreage, spacious 0.82161 units with a confidence level of 99\%. So did the opposite.

Table 3. Analysis result 2SLS soybean extensive acreage of Indonesia models. (Badan Pusat Statistik, 2015 (Data Processed)).

\begin{tabular}{lrlc}
\hline \multicolumn{1}{c}{ Var } & Koef & t-statistic & $\begin{array}{c}\text { p- } \\
\text { value }\end{array}$ \\
\hline Konst & 328511.4 & 1.965 & 0.063 \\
PKDt & 108.9005 & $1.741^{*}$ & 0.096 \\
PJDt & -340.0321 & $-2.077^{* *}$ & 0.050 \\
At-1 & 0.82161 & $9.285^{* * *}$ & 0.000 \\
\hline R-square & & 0.938 & \\
F-stat & & 103.231 & \\
p-value & & 0.000 & \\
\hline
\end{tabular}

Description:

*** : Significance on the level of trust $99 \%$ $(\alpha=1 \%)$

$* * \quad$ : Significance on the level of trust $95 \%$ $(\alpha=5 \%)$

* $\quad$ : Significance on the level of trust $90 \%$ $(\alpha=10 \%)$

2. The Factors That Affect The Productivity of Soybean Indonesia

Based on the results of the calculations which are obtained that the value of the F- statistic (105.927) is larger than F-table (7.938) which means that the variables are exogenous effect together/simultaneous to soybean productivity. The value of the coefficient of determination (R-square) which acquired for 0.937 or $93.7 \%$ variation shows that the productivity of soybean Indonesia can be explained by exogenous variables that include the price of domestic soybean (PKDt), fertilizer prices (Pxt), and soybean productivity a year earlier (YPKt-1) 6.3\%, while that of soybean productivity variation explained by other factors outside the model. Factors that affect the productivity of soybean Indonesia are as follows:

Table 4. Analysis results 2SLS soybean productivity Indonesia models (Badan Pusat Statistik, 2015 (Data Processed)).

\begin{tabular}{lrlc}
\hline \multicolumn{1}{c}{ Var } & \multicolumn{1}{c}{ Koef } & t-statistic & $\begin{array}{c}\text { p- } \\
\text { value }\end{array}$ \\
\hline Konst & 0.791805 & 3.644 & 0.001 \\
PKDt & 0.0000233 & $3.592 * * *$ & 0.002 \\
PXt & -0.000824 & $-2.122 * *$ & 0.046 \\
YPKt-1 & 0.332194 & $1.850 *$ & 0.079 \\
\hline R-square & & 0.937 & \\
F-statistik & & 105.927 & \\
P-value & & 0.000 & \\
\hline Keterangan & & &
\end{tabular}

Keterangan:

$* * * \quad$ : Significance on the level of trust $99 \%$ $(\alpha=1 \%)$

** : Significance on the level of trust $95 \%$ $(\alpha=5 \%)$

* $\quad$ : Significance on the level of trust $90 \%$ $(\alpha=10 \%)$

a. The Price of Domestic Soybean

Prices of domestic soybean has a positive effect against domestic soybean productivity. It can be observed from the results of the test $t$ with p-value (0.002) a significant level of error of $1 \%$. The value of domestic soybean price parameter coefficient $(0.0000233)$ indicates that in the event of domestic soybean price increased by 1 unit, then it would cause a rise or increase productivity of soybean 0.0000233 unit, with a confidence level of $99 \%$. So did the opposite.

b. The Price of Fertilizer

Prices of fertilizer has a negative effect to the productivity of soybean in Indonesia. It is observed from the $t$ value with $p$-value (0.046) to a significant extent on the error of $5 \%$. The value of coefficient parameters of fertilizer prices ($0.000824)$ indicates that if the fertilizer price 
increases by 1 unit, then it will cause a decrease in productivity of soybean 0.000824 unit with a confidence level of $95 \%$. So did the opposite.

c. Productivity of Soybean in Previous Year

Productivity of Soybean in previous has a positive effect against the productivity of soybean in Indonesia. It is apparent from the $t$ value with $p$-value (0.079) a significant level of errors of $10 \%$. The value of the parameter the coefficient productivity of soybeans a year earlier (0.332194) shows that in case of increase of productivity of soybeans a year earlier by 1 unit, then it would cause a rise or increase productivity of soybean 0.332194 unit with a confidence level of $90 \%$.

3. The Factors That Affect The Demand for Soybeans Indonesia

Based on the results of the calculations are obtained that the value of the F-statistic (8.898) is greater than the F-table (7.096) which means that the variables are exogenous effect together/simultaneous against soybean demand. The value of the coefficient of determination (Rsquare) which acquired for 0603 showed that $60.3 \%$ soybean demand variation can be explained by exogenous variables that include the price of domestic soybean (PKDt), population $(\mathrm{Ntt})$, the income of residents (Ytt), and the price of domestic corn (PJdt), while soybean demand $39.7 \%$ variation explained by other factors outside the model. Factors that affect the demand for domestic soybean are as follows:

a. The Price of Domestic Soybean

Price of domestic soybean has a negative effect against of soybean demands in Indonesia. It is observed from the $\mathrm{t}$ value with $\mathrm{p}$-value (0.027) are significant at a 5\% error level. The value of the coefficient of domestic soybean price parameters $(-572,1952)$ indicates that in the event of domestic soybean price increases by 1 unit, then it will lead to a decreased in demand for soybeans amounted to 572,1952 units with a confidence level of $95 \%$. So did the opposite.

b. Population

Population has a positive effect towards indonesia's soybean demand. It is observed from the $t$ value with $p$-value $(0.004)$ to a significant extent on the error of $1 \%$. The value of the coefficient of a population parameter (44.34047) shows that if arise in population of 1 unit, then it would cause arise or increase the demand for soybeans amounted to 44.34047 units with a confidence level of $99 \%$. So did the opposite.

\section{c. Real Incomes}

Incomes has no effect against the demand of soybean in indonesia. It is apparent from the $t$ value with p-value (0.433) that are not significant at a $10 \%$ error level.

\section{d. Domestic Corn Price}

Corn Price has no effect against the real domestic demand for soybean in Indonesia. It is apparent from the $t$ value with p-value (0.183) that are not significant at a $10 \%$ error level.

Table 5. Analysis result 2SLS soybean demand models. (Badan Pusat Statistik, 2015 (Data Processed)).

\begin{tabular}{lrlc}
\hline \multicolumn{1}{c}{ Var } & \multicolumn{1}{c}{ Koef } & $\begin{array}{c}\text { t- } \\
\text { statistic }\end{array}$ & $\begin{array}{c}\text { p- } \\
\text { value }\end{array}$ \\
\hline Konst & -5664661 & -2.686 & 0.014 \\
PKDt & -572.1952 & $-2.395^{* *}$ & 0.027 \\
Ntt & 44.34047 & $3.276^{* * *}$ & 0.004 \\
Ytt & 0.02094 & 0.800 & 0.433 \\
PJDt & 825.8755 & 1.379 & 0.183 \\
\hline R-square & & 0.603 & \\
F-statistik & & 8.898 & \\
P-value & & 0.000 & \\
\hline Keterangan & & &
\end{tabular}

Keterangan:

$* * * \quad$ : Significance on the level of trust $99 \%$ $(\alpha=1 \%)$

$* * \quad$ : Significance on the level of trust $95 \%$ $(\alpha=5 \%)$

* : : Significance on the level of trust $90 \%$ $(\alpha=10 \%)$

4. The Factors That Affect The Price of Soybeans Indonesia

Based on the results of the calculations which are obtained that the value of the Fstatistic (124.28) is greater than the F-table (6.355) which means that the variables are exogenous effect together/ simultaneous domestic soybean price. The value of the coefficient of determination (R-square) which acquired for 0.972 or $97.2 \%$ variation showed that the price of domestic soybean can be explained by exogenous variables that include the price of soybeans world (PKWt), the demand for soybeans (QDKIt), soybean (QSKIt) offer, the exchange rate (Er), the import tariff of soybean (TMK), and the price of domestic soybean a year earlier (PKDt-1) 2.8\%, whereas the price of 
domestic soybean variation explained by other factors outside the model.

Table 6. Analysis result 2 SLS price soybean models. (Badan Pusat Statistik, 2015 (Data Processed)).

\begin{tabular}{lrlc}
\hline \multicolumn{1}{c}{ Var } & \multicolumn{1}{c}{ Koef } & t-statistic & $\begin{array}{c}\text { p- } \\
\text { value }\end{array}$ \\
\hline Konst & 13252 & 3.664 & 0.002 \\
PKWt & 0.929332 & $2.519^{* *}$ & 0.021 \\
QSKIt & -0.001929 & $-2.063^{*}$ & 0.053 \\
ER & 0.158063 & $1.875^{*}$ & 0.077 \\
TMK & 95.47354 & $1.834^{*}$ & 0.083 \\
PKDt-1 & 0.822469 & $4.428^{* * *}$ & 0.000 \\
\hline R-square & & 0.972 & \\
F-statistik & & 108.86 & \\
P-value & & 0.000 & \\
\hline
\end{tabular}

\begin{tabular}{|c|c|}
\hline \multicolumn{2}{|c|}{ Keterangan: } \\
\hline$* * *$ & $\begin{array}{l}\text { : Significance on the level of trust } 99 \% \\
(\alpha=1 \%)\end{array}$ \\
\hline$* *$ & $\begin{array}{l}\text { Significance on the level of trust } 95 \% \\
(\alpha=5 \%)\end{array}$ \\
\hline$*$ & $\begin{array}{l}\text { : Significance on the level of trust } 90 \% \\
(\alpha=10 \%)\end{array}$ \\
\hline
\end{tabular}

a. Soybean World Price

Soybean world price had positive effect to the soybean price in Indonesia. It is apparent from the $\mathrm{t}$ value with $\mathrm{p}$-value $(0.021)$ are significant at a $5 \%$ error level. The value of the coefficient of the world soybean prices parameter $(0.929332)$ indicates that if there is increasing in every 1 unit of the soybeans world price, then it would cause an increase in the price of domestic soybean 0.929332 unit with a confidence level of 95\%. So did the opposite.

\section{b. Soybean Supply}

Soybean Supply has a negative effect to the price of soybean in indonesia. It is observed from the $t$ value with $p$-value (0053) which is significant at the $10 \%$ error level. The value of the coefficient of soybean supply parameters (0,001929 ) indicates that if the increase in supply of soybeans by 1 unit, then it will cause a decrease in the price of domestic soybean 0.001929 unit with a confidence level of $90 \%$. So did the opposite.

\section{c. Exchange Rate}

The exchange rate effect is positive towards the price of soybean in indonesia. It is observed from the $t$ value with $\mathrm{p}$-value $(0.077) \mathrm{a}$ significant level of errors of $10 \%$. The value of coefficient parameters exchange rates $(0.158063)$ shows that if arise in the exchange rate of 1 unit, then it would cause an increase in the price of domestic soybean 0.158063 unit with a confidence level of $90 \%$. So did the opposite.

\section{d. Import Tariff}

Import tariff has a real effect of soybean's prices in indonesia. It is apparent from the $t$ value with p-value (0.083) a significant level of errors of $10 \%$. The value of coefficient parameters exchange rates (95.47354) shows that if a rise in the exchange rate of 1 unit, then it would cause an increase in the price of domestic soybean 95.47354 unit with a confidence level of $90 \%$. So did the opposite.

e. The Price of Domestic Soybean in Previous Year

Soybean prices previous year influential real domestic price of soy in Indonesia. It is apparent from the $t$ value with p-value $(0.000)$ to a significant extent on the error of $1 \%$. The value of the coefficient of domestic soybean Price parameters of the previous year (0.822469) indicates that if the increase in the price of soybeans a year earlier by 1 unit, then it would cause a rise or increase the price of domestic soybean 0.822469 unit with a confidence level of $99 \%$. So did the opposite.

\section{Factors Affecting The Soybean Import}

Table 7. Analysis result 2SLS import soybeans Indonesia models. (Badan Pusat Statistik, 2015 (Data Processed)).

\begin{tabular}{lrlc}
\hline \multicolumn{1}{c}{ Var } & Koef & \multicolumn{1}{c}{$\begin{array}{c}\mathbf{t}- \\
\text { statistic }\end{array}$} & $\begin{array}{c}\text { p- } \\
\text { value }\end{array}$ \\
\hline Konst & 1226698 & 1.817 & 0.085 \\
QKIt & -0.665098 & $-2.426^{* *}$ & 0.025 \\
QDKIt & 0.749969 & $3.526^{* * *}$ & 0.002 \\
TMK & -51505.84 & $-2.359^{* *}$ & 0.029 \\
PKWt & -120.442 & -1.557 & 0.136 \\
ER & 0.889665 & -0.295 & 0.772 \\
\hline R-square & & 0.820 & \\
F-statistik & & 16.905 & \\
P-value & & 0.000 & \\
\hline
\end{tabular}

Keterangan:

*** $\quad$ Significance on the level of trust $99 \%$ $(\alpha=1 \%)$

** : Significance on the level of trust $95 \%$ $(\alpha=5 \%)$

* $\quad$ : Significance on the level of trust $90 \%$ $(\alpha=10 \%)$ 
Based on the results of the calculations, the value of the F-statistic (16.905) is greater than the F-table (6.622), which means that the variables are exogenous effect together/simultaneous against imports of soybeans. The value of the coefficient of determination (R-square) which acquired for 0.820 or $82.0 \%$ variation shows that imports of soybeans can be explained by exogenous variables that include the production of soybeans (QKIt), the demand for soybeans (QDKIt), the import tariff (TMK), world soybean prices (PKWt), and the exchange rate (ER) $18.0 \%$ variation, while the import of soy explained by other factors outside the model. Factors affecting the soybean imports are as follows:

a. The Production of Soybeans

Soybean Production has negative effect againts soybean import in indonesia. It is observed from the $t$ value with $p$-value $(0.025)$ a significant level of error of $5 \%$. The value of the coefficient of soybean production parameters (0,665098 ) shows that if a rise in domestic soybean production by 1 unit, then it will cause a decrease in imports of soybeans amounted to 0.665098 units with a confidence level of $95 \%$. So did the opposite.

\section{b. Demand of Soybeans}

Soybean demand has positive effect against imports of soybean in Indonesia. It is apparent from the $t$ value with p-value (0.002) a significant level of error of $1 \%$. The value of the query parameter coefficients soybeans (0.749969) indicates that in the event of a rise in demand for soybeans soybeans by 1 unit, then it would cause an increase in imports of soybeans amounted to 0.749969 units with a confidence level of $99 \%$. So did the opposite.

c. The Import Tariff

Imports tariff of soybean has negative effect imports soybean in Indonesia. It is apparent from the $t$ value with p-value (0.029) are significant at a $5 \%$ error level. The value of the coefficient of the import tariff parameters (51505.84) indicates that if the tariff import of soybeans by 1 unit, then it will cause a decrease in imports of soybeans amounted to 51505.84 units with a confidence level of $95 \%$. So did the opposite.

\section{d. Soybean World Price}

Soybean world price has no real effect against import of soybean in indonesia. It is apparent from the $t$ value with $\mathrm{p}$-value $(0.136)$ a significant level of errors of $10 \%$. High soybean prices low so that the world does not affect import of soybean in Indonesia.

\section{e. The Exchange Rate}

The exchange rate had no real effect against the demand of soybean in indonesia. It is apparent from the $t$ value with p-value (0.772) that are not significant at a $10 \%$ error level. So the high to the low exchange rate does not affect the import of soybean in Indonesia.

\subsection{Policy Alternatives to Reduce Import of Soybean In Indonesia}

Table 8. The results of the validation economic models soybeans Indonesia. (Badan Pusat Statistik, 2015 (Data Processed)).

\begin{tabular}{crrrrr}
\hline $\begin{array}{c}\text { Var. } \\
\text { Endo }\end{array}$ & $\begin{array}{c}\text { RMS } \\
\text { \% } \\
\text { Error }\end{array}$ & $\begin{array}{c}\text { Bias } \\
(\mathbf{U M})\end{array}$ & $\begin{array}{c}\text { Var } \\
(\mathbf{U S})\end{array}$ & $\begin{array}{c}\text { Cov } \\
(\mathbf{U C})\end{array}$ & $\begin{array}{c}\text { U- } \\
\text { Theil }\end{array}$ \\
\hline AT & 30.951 & 0.04 & 0.03 & 0.92 & 0.23 \\
YPKT & 4.782 & 0.01 & 0.02 & 0.97 & 0.03 \\
QDKIT & 23.598 & 0.04 & 0.03 & 0.93 & 0.22 \\
PKDT & 6.828 & 0.02 & 0.07 & 0.91 & 0.16 \\
MKIT & 3,056 & 0.04 & 0.05 & 0.91 & 0.11 \\
QKIT & 13.330 & 0.03 & 0.00 & 0.97 & 0.02 \\
QSKIT & 11.941 & 0.05 & 0.24 & 0.71 & 0.13 \\
\hline
\end{tabular}

Based on the value of the indicator of the average quadratic error of the smallest (RMSPE) that fairly small pointed out that the results of the drilling program at the values of endogenous variables don't stray too far from the actual values. The UM value close to zero means that the proportion of bias between the value of the simulation with actual value is very small. The value of US close to zero indicates that the regression slope very small irregularities. The UC value approaching one shows that the residual bias component is also very small. Then for the value of $U$ is generally close to zero shows that the model in this study had already been used for the simulation.

It is supported with the results or the average value of the actual data and the predicted value is almost the same. According to Sumarno and Adie (2013), production proven policy can increase the production of soybean in Indonesia, thus simulating the production development policy conducted. 
1. Expansion of Soybean Harvest Area Indonesia Scenario

Based on the results of the harvest expansion policy simulation of harvesting soybeans in Indonesia (15\%) can decrease soybean imports to reach 881,061 tons.

Table 9. The results of the simulation soybean acreage expansion policy $(15 \%)$. (Badan Pusat Statistik, 2015 (Data Processed)).

\begin{tabular}{ccccc}
\hline Variable & initial & Simulati & \multicolumn{2}{c}{ Changes } \\
\cline { 3 - 5 } values & on Value & value & $\begin{array}{c}\text { Persenta } \\
\text { se (\%) }\end{array}$ \\
\hline AT & 1200471 & 1381344 & 180873 & 15.07 \\
YPKT & 285.3 & 325.2 & 39.9 & 13.99 \\
QDKIT & 2078623 & 2234261 & 155638 & 7.49 \\
PKDT & 6275.9 & 5947 & -328.9 & -5.24 \\
MKIT & 1252919 & 490925 & -761994 & -60.82 \\
QKIT & 1279569 & 1666969 & 387400 & 30.28 \\
QSKIT & 2964233 & 3267359 & 303126 & 10.23 \\
\hline
\end{tabular}

2. Increased Productivity Scenario

The effect of simulation policy increased productivity, can decrease the import of soybean in Indonesia amounted to 714,182 tonnes.

Table 10. Policy simulation result increased productivity (10\%). (Badan Pusat Statistik, 2015 (Data Processed)).

\begin{tabular}{ccccc}
\hline \multirow{2}{*}{ Variable } & \multirow{2}{*}{$\begin{array}{c}\text { initial } \\
\text { values }\end{array}$} & $\begin{array}{c}\text { Simulation } \\
\text { Value }\end{array}$ & \multicolumn{2}{c}{ Changes } \\
\cline { 4 - 6 } & & & value & $\begin{array}{c}\text { Persenta } \\
\text { se (\%) }\end{array}$ \\
\hline AT & 1200471 & 1321641 & 121170 & 10.09 \\
YPKT & 285.3 & 313.9 & 28.6 & 10.02 \\
QDKIT & 2078623 & 2308162 & 229539 & 11.04 \\
PKDT & 6275.9 & 5578.5 & -697.4 & -11.11 \\
MKIT & 1252919 & 538737 & -714182 & -57.00 \\
QKIT & 1279569 & 1313179 & 33610 & 2.63 \\
QSKIT & 2964233 & 3213539 & 249306 & 8.41 \\
\hline
\end{tabular}

3. The Granting ff Subsidies On Fertilizer Prices Scenario

The impact of the grant of the subsidy policy simulation fertilizer prices, can lower the import of soybean in Indonesia amounted to 769,888 tonnes.
Table 11. Results of simulation policy of granting subsidies to fertilizer prices (10\%). (Badan Pusat Statistik, 2015 (Data Processed)).

\begin{tabular}{ccccc}
\hline \multirow{2}{*}{ Variable } & \multirow{2}{*}{$\begin{array}{c}\text { initial } \\
\text { values }\end{array}$} & $\begin{array}{c}\text { Simulation } \\
\text { value }\end{array}$ & \multicolumn{2}{c}{ changes } \\
\cline { 5 - 6 } & & & & $\begin{array}{c}\text { Persentase } \\
(\%)\end{array}$ \\
\hline AT & 1200471 & 1223717 & 23246 & 1.94 \\
YPKT & 285.3 & 313.1 & 27.8 & 9.74 \\
QDKIT & 2078623 & 2278569 & 199946 & 9.62 \\
PKDT & 6275.9 & 6164.8 & -111.1 & -1.77 \\
MKIT & 1252919 & 483031 & -769888 & -61.45 \\
QKIT & 1279569 & 1313179 & 33610 & 2.63 \\
QSKIT & 2964233 & 3213539 & 249306 & 8.41 \\
\hline
\end{tabular}

\section{Conclusions}

Soybean production in the past 26 years, namely 1989 to 2014 tend to decline each year. While the demand for and imports of soybeans each year continues to increase along with the price of domestic soybean and soybean prices world also increase every year.

Factors that affect the economic performance of soybean in Indonesia; (a) the acreage of the soy harvest is influenced by the price of domestic soybean harvest soybean acreage, area in the previous year, and the price of domestic corn. (b) productivity of soybean are influenced by the price of domestic soybean, soybean productivity a year earlier, and the price of fertilizer. (c) demand for soybeans is affected by population, and domestic soybean price. (d) the price of domestic soybean affected by soybean prices, world imports, tariffs, exchange rates and the supply of soybeans. (e) the import of soybean in Indonesia are influenced by the demand for soybeans, production of soybeans, soybean imports and tariffs.

There are several scenarios that policy can be used to reduce the import of soybean in Indonesia among them; (a) conduct the policy of expansion of $15 \%$ of the soybean crop that can decrease the amount of soybean imports amounting to $60.82 \%$, (b) the policy of increased productivity by $10 \%$ soybean can lower the amount of soybean imports amounted to 57\%, and (c) the policy of granting subsidies to fertilizer prices by $10 \%$ that can decrease the amount of soybean imports of $61.45 \%$. 


\section{References}

[1]. Amang, B. dan Sawit, M. H. (1996). Ekonomi Kedelai: Rangkuman. Dalam: Amang, B., M.H. Sawit, dan A. Rachman (Eds). Ekonomi Kedelai di Indonesia. IPB Press.

[2]. Badan Pusat Statistik (BPS). 2014. Impor Tanaman Pangan (online).http: //www.bps.go.id/site/resultTab. Direktorat Jenderal Perkebunan, Departemen Pertanian. Diakses pada 20 Maret 2015.

[3]. Badan Pusat Statistik (BPS). 2014. Konsumsi Kedelai (online).http: //www.bps.go.id/site/resultTab. Direktorat Jenderal Perkebunan, Departemen Pertanian. Diakses pada 20 Maret 2015.

[4]. Badan Pusat Statistik (BPS). 2015. Perkembangan Luas Areal Kedelai, Produksi, Produktivitas Indonesia (online). http: //www.bps.go. Id/site/ resultTab. Direktorat Jenderal Perkebunan, Departemen Pertanian. Diakses pada 20 Maret 2015.

[5]. Gujarati, D. N. 2012. Dasar-Dasar Ekonometrika Buku 1. Jakarta: Penerbit Salemba Empat.

[6]. Halwani, H. 2005. Ekonomi Internasional dan Globalisasi Ekonomi.Bogor: Ghalia Indonesia.

[7]. Indradewa, D. 2013. Indonesia Krisis Kedelai (online).https://ugm.ac.id/id/ berita/ 8192-pakar. ugm: indonesia. krisis. kedelai. karena. lahan. berkurang.Diakses pada 20 Maret 2015.

[8]. Purwono, L. dan Purnamawati. 2007. Budidaya Tanaman Pangan. Agromedia: Jakarta.

[9]. Sudaryanto, T. dan Swastika, D. K. S. 2007. Ekonomi Kedelai di Indonesia. Forum Agro Ekonomi (FAE) 12 (3): 1-27.

[10]. Sumarno dan Adie, M. M. 2013. Strategi Pengembangan Produksi Menuju Swasembada Kedelai Berkelanjutan. Jurnal.

[11]. Supadi. 2009. Dampak Impor Berkelanjutan Terhadap Ketahanan Pangan. Dalam Jurnal Analisis Kebijakan Pertanian. Vol 7 No 1: 87-102. 